\title{
Termin na wydanie decyzji o ustaleniu opłaty adiacenckiej (art. 145 ust. 2 u.g.n.)
}

Wyrok Naczelnego Sądu Administracyjnego z dnia 8 października 2019 r., I OSK 85/18

Wyrok Naczelnego Sądu Administracyjnego z dnia 16 października 2019 r., IOSK 200/18

1. Decyzją określoną w art. 145 ust. 2 zdanie pierwsze ustawy o gospodarce nieruchomościami (o treści obowiązującej przed 23 sierpnia 2017 r.) jest decyzja organu pierwszej instancji niezależnie od tego, czy decyzja ta w wyznaczonym przez ustawodawcę terminie trzech lat stała się ostateczna i niezależnie od tego, czy to ta decyzja stała się ostateczna.

2. W sytuacji, w której przed upływem trzyletniego terminu, o którym mowa w tym przepisie, wydana została decyzja organu pierwszej instancji, późniejsze jej uchylenie nie wyłącza możliwości ustalenia opłaty adiacenckiej poprzez wydanie kolejnej decyzji.

\section{Andrzej Matan}

Uniwersytet Śląski w Katowicach

andrzej.matan@gmail.com

ORCID: 0000-0003-1155-2495

https://doi.org/10.26881/gsp.2020.2.12

\section{Glosa}

1. Oba wyroki ${ }^{1}$ Naczelnego Sądu Administracyjnego (NSA) stanowią wspólny przedmiot glosy, dotyczą bowiem identycznego stanu faktycznego i prawnego². Łączy je pogląd wyrażany w uzasadnieniu przez składy orzekające, zgodnie z którym

\footnotetext{
1 Wyrok NSA z dnia 8 października 2019 r., I OSK 85/18, LEX nr 2734948 (dalej: pierwszy); oraz wyrok NSA z dnia 16 października 2019 r., I OSK 200/18, LEX nr 2748529 (dalej: drugi).

2 Wyroków takich zapadło ponad 40, były podejmowane w różnych terminach, dotyczyły jednej z gmin województwa śląskiego. Wybrane do glosowania wyroki są opatrzone uzasadnieniami reprezentującymi dwa nurty, zbieżne co do konkluzji, odmienne jednak po części, jeśli chodzi o argumentację.
} 
trzyletni termin do wydania decyzji o ustaleniu opłaty adiacenckiej, przewidziany w art. 145 ust. 2 zdanie drugie ustawy o gospodarce nieruchomościami ${ }^{3}$, oznacza wydanie w tym terminie decyzji przez organ pierwszej instancji „niezależnie od tego, czy decyzja ta w wyznaczonym przez ustawodawcę terminie trzech lat stała się ostateczna i niezależnie od tego, czy to ta decyzja stała się ostateczna"4.

2. Stan faktyczny i prawny sprawy, zrekonstruowany na podstawie uzasadnienia wyroku drugiego, był następujący ${ }^{5}$.

Organ pierwszej instancji, działając na podstawie art. 145 i 146 u.g.n., w związku z uchwałą rady gminy w sprawie ustalenia wysokości stawki procentowej opłaty adiacenckiej, w drodze decyzji doręczonej przed upływem terminu trzyletniego ustalił opłatę adiacencką z tytułu wzrostu wartości nieruchomości gruntowej spowodowanej stworzeniem warunków do podłączenia tej nieruchomości do urządzeń infrastruktury technicznej - sieci kanalizacji sanitarnej.

Organ drugiej instancji, po rozpatrzeniu odwołania decyzją wydaną już po upływie terminu trzyletniego, utrzymał rozstrzygnięcie pierwszoinstancyjne w mocy.

W wyniku skargi wniesionej przez stronę, WSA w Gliwicach wyrokiem, wydanym już po zmianie art. 145 ust. 2 u.g.n., uchylił decyzje organów obu instancji oraz umorzył postępowanie administracyjne. W ocenie sądu, operat obarczony był zarówno formalnymi, jak i merytorycznymi wadami powodującymi, iż nie mógł on stanowić podstawy ustalenia przez organ opłaty adiacenckiej. Z tego powodu zostały uchylone decyzje organów administracji obu instancji.

Ponadto, sąd pierwszej instancji w pkt 2 wyroku umorzył postępowanie administracyjne, stwierdzając brak przesłanek określonych w art. 145 ust. 2 u.g.n. w zw. z art. 4 ust. 3 ustawy zmieniającej ${ }^{6}$ u.g.n. do prowadzenia postępowania, albowiem upłynął termin trzech lat, w trakcie których organ ma kompetencje do wydania decyzji określającej opłatę adiacencką. Sąd podkreślił, że wyeliminowanie z obrotu prawnego decyzji ustalającej wysokość opłaty adiacenckiej, jeżeli upłynął już trzyletni termin do jej wydania, powoduje, że organ traci kompetencje do ponownego wydania ustalającego opłatę rozstrzygnięcia.

Od powyższego wyroku skargę kasacyjną złożył organ odwoławczy, zaskarżając go w części określonej w pkt 2, tj. w zakresie orzeczenia o umorzeniu postępowania administracyjnego. Wyrokowi zarzucono naruszenie przepisów prawa materialnego, tj. art. 145 ust. 2 u.g.n. poprzez nieprawidłowe przyjęcie, że wyeliminowanie z obrotu prawnego decyzji ustalającej wysokość opłaty adiacenckiej, jeżeli upłynął już trzyletni termin do jej wydania, powoduje, że organ traci kompetencje do ponownego wydania rozstrzygnięcia ustalającego opłatę.

3 Ustawa z dnia 21 sierpnia 1997 r. o gospodarce nieruchomościami (tekst jedn.: Dz. U. z 2016 r., poz. 2147 ze zm.; dalej: u.g.n.).

${ }^{4}$ Zob. wyżej teza $\mathrm{nr} 1$ (pierwszego glosowanego orzeczenia).

5 Typowy stan faktyczny i prawny dla analizowanych wyroków, a także dla pozostałych wyroków wskazanych w przyp. 2.

6 Ustawa z dnia 20 lipca 2017 r. o zmianie ustawy o gospodarce nieruchomościami oraz niektórych innych ustaw (Dz. U. poz. 1509, dalej: ustawa zmieniająca u.g.n., ustawa z dnia 20 lipca 2017 r.). 
W uzasadnieniu skargi kasacyjnej powołano się na uchwałę NSA z dnia 27 lipca 2009 r., I OPS 4/09. Według organu odwoławczego, po uchyleniu przez sąd administracyjny decyzji ustalającej opłatę adiacencką, możliwe jest dalsze prowadzenie postępowania administracyjnego. Powołano się na ustawę zmieniającą u.g.n. - wskazano, że zmianie uległ m.in. art. 145 ust. 2 u.g.n. Zdaniem autora skargi kasacyjnej, intencją ustawodawcy było i jest umożliwienie prowadzenia postępowań i wydawanie decyzji ustalających opłaty adiacenckie także po upływie trzech lat po dniu stworzenia warunków do podłączenia nieruchomości do poszczególnych urządzeń infrastruktury technicznej albo od dnia stworzenia warunków do korzystania z wybudowanej drogi. Podniesiono także, że przy rozpoznawaniu sprawy wyłoniło się zagadnienie prawne budzące poważne wątpliwości, wobec czego zasadne byłoby rozważenie przez sąd przedstawienia tej kwestii do rozstrzygnięcia składowi siedmiu sędziów NSA w trybie art. 187 § 1 oraz art. 264 i n. prawa o postępowaniu przed sądami administracyjnymi

W obu glosowanych sprawach NSA uchylił zaskarżony wyrok w części dotyczącej umorzenia, przy czym w pierwszym wyroku orzekł także o przekazaniu sprawy do ponownego rozpoznania Wojewódzkiemu Sądowi Administracyjnemu (WSA) w Gliwicach, zaś w drugim poprzestał tylko na umorzeniu.

Aby odnieść się do wyroków, trzeba zapoznać się z ich uzasadnieniami, które są różne, ale jednocześnie typowe dla dwu „linii” orzeczniczych, które zostały ukształtowane w analogicznym stanie faktycznym i prawnym, jak również jednolitej linii prezentowanej przez WSA w Gliwicach w zakresie dopuszczalności orzekania przez organ pierwszej instancji po uchyleniu jego decyzji przez WSA.

Poniżej argumentacja przywołana w uzasadnieniu pierwszego wyroku (z dnia 8 października 2019 r., I OSK 85/18).

„Spór dotyczy rozumienia treści cytowanego wyżej art. 145 ust. 2 zdanie pierwsze ustawy o gospodarce nieruchomościami w zakresie pojęcia: »wydanie decyzji o ustaleniu opłaty adiacenckiej może nastąpić w terminie do 3 lat«. Wykładnia tego pojęcia budziła w przeszłości wątpliwości prawne, dlatego w uchwale składu siedmiu sędziów z dnia 27 lipca 2009 r., I OPS 4/09, Naczelny Sąd Administracyjny wyjaśnił, że: »Trzyletni termin, o którym mowa w art. 145 ust. 2 ustawy z dnia 21 sierpnia 1997 r. o gospodarce nieruchomościami (Dz. U. z 2004 r. Nr 261, poz. 2603 ze zm.), dotyczy rozstrzygnięcia przez organ pierwszej instancji o ustaleniu opłaty adiacenckiej«. Z cytowanej treści sentencji uchwały nie wynika, aby zachowanie ustawowo określonego terminu trzech lat dotyczyło wydania decyzji ostatecznej. Wręcz przeciwnie, w uzasadnieniu tej uchwały wskazano, że upływ tego terminu należy wiązać z wydaniem decyzji przez organ administracji orzekający w pierwszej instancji niezależnie od tego, czy decyzja ta stanie się w tym terminie ostateczna, czy też stanie się ostateczna dopiero po upływie tego terminu na skutek np. wniesienia odwołania i rozpatrzenia sprawy przez organ odwoławczy.

\footnotetext{
7 Ustawa z dnia 30 sierpnia 2002 r. - Prawo o postępowaniu przed sądami administracyjnymi (Dz. U. $\mathrm{Nr} 153$, poz. 1270; dalej: p.p.s.a.).
} 
Z powyższego wynika, że decyzją określoną w art. 145 ust. 2 zdanie pierwsze ustawy o gospodarce nieruchomościami (o treści obowiązującej przed 23 sierpnia 2017 r.) jest decyzja organu pierwszej instancji niezależnie od tego, czy decyzja ta, w wyznaczonym przez ustawodawcę terminie trzech lat, stała się ostateczna i niezależnie od tego, czy to ta decyzja stała się ostateczna.

(...) Sąd pierwszej instancji błędnie uznał, że postępowanie administracyjne o ustalenie opłaty adiacenckiej w niniejszej sprawie należało umorzyć, jako bezprzedmiotowe. Postępowanie to mogło się bowiem toczyć, skoro określony przez ustawodawcę warunek samego wydania decyzji przez organ pierwszej instancji w terminie trzech lat od dnia stworzenia warunków do podłączenia nieruchomości do poszczególnych urządzeń infrastruktury technicznej został spełniony, a następnie organ odwoławczy mógłby skorzystać ze swojego ustawowego uprawnienia do wydania decyzji na podstawie art. 138 § 2 kpa.

W związku z powyższym Naczelny Sąd Administracyjny, na podstawie art. $185 \S 1$ ustawy z dnia 30 sierpnia 2002 r. - Prawo o postępowaniu przed sądami administracyjnymi (Dz. U. z 2018 r. poz. 1302, ze zm.) - dalej ppsa, uchylił pkt 2 zaskarżonego wyroku i w tym zakresie przekazał sprawę do ponownego rozpoznania Sądowi pierwszej instancji".

Nieco inaczej rozłożono akcenty w uzasadnieniu drugiego wyroku (z dnia 16 października 2019 r., I OSK 200/18).

„Przypomnieć należy w tym miejscu, że obowiązek uiszczenia opłaty adiacenckiej o której mowa w art. 145 ustawodawca powiązał ze stworzeniem warunków do podłączenia nieruchomości do poszczególnych urządzeń infrastruktury technicznej albo ze stworzeniem warunków do korzystania z wybudowanej drogi i jednocześnie ze wzrostem wartości nieruchomości. Nie jest wystarczające samo stworzenie warunków do podłączenia nieruchomości do określonych urządzeń infrastruktury technicznej, czy też możliwości korzystania z wybudowanej drogi. Elementem koniecznym jest również wzrost wartości nieruchomości. Dla obowiązku poniesienia opłaty adiacenckiej nie ma przy tym znaczenia, czy dany właściciel nieruchomości zamierza korzystać z nowej infrastruktury czy drogi, istotne jest jedynie że taką możliwość uzyskał i że w jej następstwie wzrosła wartość jego majątku.

Dodatkowo należy mieć na względzie, że przepisy rozdziału 7 ustawy z 21 sierpnia 1997 roku stosuje się jeżeli urządzenia infrastruktury technicznej zostały wybudowane z udziałem środków Skarbu Państwa, jednostek samorządu terytorialnego, środków pochodzących z budżetu Unii Europejskiej lub ze źródeł zagranicznych niepodlegających zwrotowi (art. 143 ustawy z 21 sierpnia 1997 roku).

Jak wskazuje się w doktrynie, »opłaty adiacenckiej nie wskazano wprost jako dochodu gminy w ustawie z 13.11.2003 r. o dochodach jednostek samorządu terytorialnego (Dz. U. z 2018 r. poz. 1530 ze zm.). Jest to jednak wymieniona w art. 4 ust. 1 pkt 2 lit. $f$ tej ustawy jedna $z$ innych opłat stanowiących dochody gminy, uiszczanych na podstawie odrębnych przepisów« (por. Ewa Bończak-Kucharczyk, Art. 144. W: Ustawa o gospodarce nieruchomościami. Komentarz aktualizowany. System Informacji Prawnej LEX, 2019.). 
Opłata adiacencka uiszczana w związku z zaistnieniem okoliczności o których mowa w art. 145 i 146 ustawy z 21 sierpnia 1997 roku jest więc powiązana z faktem zwiększenia wartości nieruchomości przy wykorzystaniu środków publicznych.

Dla ochrony interesów właściciela nieruchomości wystarczające jest zatem, aby w okresie trzech lat od dnia stworzenia warunków, o których mowa w art. 145 ust. 2 ustawy z 21 sierpnia 1997 roku doszło do wydania decyzji ustalającej wysokość opłaty adiacenckiej, bez względu na to, czy decyzja ta zostanie następnie uchylona przez organ drugiej instancji czy też przez sąd administracyjny. Z chwilą wydania decyzji o ustaleniu opłaty adiacenckiej przez organ pierwszej instancji ulega konkretyzacji zamiar jednostki samorządu terytorialnego do skorzystania z uprawnienia przewidzianego w art. 145 ust. 1 ustawy z 21 sierpnia 1997 roku. Ustaje zatem stan niepewności co do tego, czy opłata adiacencka zostanie nałożona czy też nie. Sytuacji tej nie zmienia ewentualne późniejsze uchylenie decyzji organu pierwszej instancji czy to przez organ odwoławczy, czy to przez sąd administracyjny.

Przyjęcie odmiennej wykładni prowadziłoby, jak słusznie wskazało Kolegium, do różnicowania sytuacji stron postępowania w zależności od tego, czy sąd administracyjny uchylił decyzję wyłącznie organu drugiej instancji czy też organów obu instancji. Mogłoby również doprowadzić do sytuacji, w której dany właściciel nie uczestniczyłby w kosztach budowy infrastruktury wpływającej na wartość jego nieruchomości tylko z tego względu, że w jego przypadku organ odwoławczy rozstrzygał na podstawie art. 138 § 2 K.p.a., bądź sąd dodatkowo skorzystał z dyspozycji art. 135 p.p.s.a. Należy też zwrócić uwagę, że późniejsze uchylenie decyzji ustalającej opłatę adiacencką nie uprawnia do przyjęcia fikcji prawnej, że nie została ona wydana. Jej wydanie przed upływem trzech lat od dnia stworzenia warunków do podłączenia nieruchomości do poszczególnych urządzeń infrastruktury technicznej spowodowało, że organ zachował kompetencje do załatwienia sprawy. Tylko brak jego decyzyjności w podanym okresie wskazywałby na utratę kompetencji.

Należy mieć również na względzie, że zgodnie z art. 145 ust. 2 ustawy z 21 sierpnia 1997 roku, w brzmieniu obowiązującym do 22 września 2004 roku, ustalenie opłaty adiacenckiej mogło nastąpić w terminie do 3 lat od dnia urządzenia lub modernizacji drogi albo od stworzenia warunków do podłączenia nieruchomości do poszczególnych urządzeń infrastruktury technicznej. Z użycia sformułowania »ustalenie« opłaty adiacenckiej wyprowadzano pogląd, iż w terminie wskazanym w owym przepisie musiało nastąpić wydanie decyzji ostatecznej. Wobec wprowadzonej od 22 września 2004 roku zmiany brzmienia tego przepisu i wskazania, że wystarczające jest samo wydanie decyzji (które nie obejmuje nawet jej doręczenia) uznać należy, że intencją ustawodawcy było umożliwienie ustalenia wysokości opłaty adiacenckiej nawet po upływie trzech lat licząc od daty stworzenia warunków do podłączenia nieruchomości do poszczególnych urządzeń infrastruktury technicznej lub stworzenia warunków do korzystania z wybudowanej drogi.

W realiach niniejszej sprawy oznacza to zatem, że brak było podstaw do zastosowania przez sąd pierwszej instancji art. 145 § 3 p.p.s.a i umorzenia postępowania administracyjnego. Organ pierwszej instancji wydał decyzję o ustaleniu opłaty adiacenckiej 
na podstawie art. 145 i 146 ustawy z 21 sierpnia 1997 roku przed upływem trzech lat od dnia zaistnienia warunków do podłączenia nieruchomości do sieci kanalizacyjnej. Uchylenie tej decyzji przez sąd administracyjny nie powoduje wygaśnięcia kompetencji organu do ustalenia opłaty adiacenckiej. Oznacza to, że sąd pierwszej instancji dokonał wadliwej wykładni art. 145 ust. 2 ustawy z 21 sierpnia 1997 roku poprzez przyjęcie, że uchylenie decyzji organu pierwszej i drugiej instancji po upływie terminu wskazanego w powołanym artykule skutkuje niemożnością ustalenia opłaty adiacenckiej. Prawidłowa wykładnia analizowanego artykułu, w brzmieniu obowiązującym w dacie wydania decyzji (...) wskazuje, że w sytuacji, w której przed upływem trzyletniego terminu o którym mowa w tym przepisie wydana została decyzja organu pierwszej instancji, późniejsze jej uchylenie nie wyłącza możliwości ustalenia opłaty adiacenckiej poprzez wydanie kolejnej decyzji".

4. Przepis art. 145 ust. 2 zdanie pierwsze u.g.n., będący podstawą prawną decyzji w dacie ich podjęcia, stanowił: „Wydanie decyzji o ustaleniu opłaty adiacenckiej może nastąpić w terminie do 3 lat od dnia stworzenia warunków do podłączenia nieruchomości do poszczególnych urządzeń infrastruktury technicznej albo od dnia stworzenia warunków do korzystania z wybudowanej drogi, jeżeli w dniu stworzenia tych warunków obowiązywała uchwała rady gminy, o której mowa w art. 146 ust. 2". Na mocy art. 1 pkt 21 ustawy zmieniającej u.g.n. uległ on zmianie, uzyskując brzmienie:„Wszczęcie postępowania w sprawie ustalenia opłaty adiacenckiej może nastąpić w terminie do 3 lat od dnia stworzenia warunków do podłączenia nieruchomości do poszczególnych urządzeń infrastruktury technicznej albo od dnia stworzenia warunków do korzystania z wybudowanej drogi, jeżeli w dniu stworzenia tych warunków obowiązywała uchwała rady gminy, o której mowa w art. 146 ust. 2".

Już pobieżna analiza obu przepisów prowadzi do wniosku, że była to zmiana o zasadniczym charakterze, skoro - ogólne rzecz ujmując - pierwotny termin do ustalenia opłaty adiacenckiej, mający charakter materialnoprawny i przedawniający, stał się terminem procesowym, co tym samym oznacza, że utracił on swoje przedawniające znaczenie.

Postępowanie organów administracji orzekających w sprawach opłaty adiacenckiej, które następnie stały się przedmiotem kontroli sądowej zakończonej glosowanymi wyrokami NSA, były prowadzone na podstawie art. 145 ust. 2 w brzmieniu obowiązującym do dnia 22 sierpnia 2017 r. Przepis międzyczasowy, zawarty w art. 4 ust. 3 ustawy zmieniającej u.g.n. nakazał stosować przepisy dotychczasowe „do postępowań, o których mowa w art. 98a ust. 1 i art. 145 ust. 2 ustawy zmienianej w art. 1, wszczętych i niezakończonych przed dniem wejścia w życie niniejszej ustawy, w zakresie terminów oraz poziomu cen nieruchomości uwzględnianych w procesie wyceny nieruchomości na potrzeby ustalenia opłaty adiacenckiej".

5. Wykładnia art. 145 ust. 2 u.g.n. w części dotyczącej terminu do wydania decyzji ustalającej opłatę adiacencką budziła od początku kontrowersje, których efektem były rozbieżności w orzecznictwie sądowym, dotyczące zwłaszcza tego, czy w terminie wskazanym w przepisie wystarczy samo wydanie decyzji, czy też wydanie i doręczenie 
decyzji przez organ pierwszej instancji, czy też wreszcie tego, że w tym terminie powinna być wydana decyzja ostateczna.

W szeregu orzeczeń sądy administracyjne prezentowały pogląd o konieczności wydania w tym terminie ostatecznej decyzji o ustaleniu opłaty adiacenckiej ${ }^{8}$. W wielu orzeczeniach dominował pogląd przeciwny, aprobujący wydanie w tym terminie decyzji przez organ pierwszej instancji ${ }^{9}$. Także w doktrynie zwracano uwagę na to, że opłata adiacencka nie jest podatkiem, lecz daniną publiczną, z którą ustawodawca wiąże powstanie roszczenia przysługującego gminie, podlegającego przedawnieniu, a zatem wszczęcie postępowania administracyjnego i wydanie decyzji przed upływem przedawnienia jest skuteczne także wówczas, gdy decyzja taka staje się ostateczna po upływie trzech lat ${ }^{10}$.

Rozbieżności z orzecznictwie miała niwelować uchwała NSA ${ }^{11}$, w której przyjęto, że trzyletni termin, o którym mowa w art. 145 ust. 2 u.g.n., dotyczy rozstrzygnięcia przez organ pierwszej instancji o ustaleniu opłaty adiacenckiej ${ }^{12}$.

Uchwała powinna była w zasadzie zakończyć okres niejednolitego orzekania i spowodować ugruntowania stanowiska, iż do zachowania trzyletniego terminu określonego w art. 145 ust. 2 u.g.n. powinno istnieć w obrocie prawnym rozstrzygnięcie organu pierwszej instancji ustalające wysokość opłaty adiacenckiej, wydane przed upływem trzech lat, przy czym rozstrzygnięcie to nie musi mieć przymiotu ostateczności ${ }^{13}$.

Orzecznictwo jednak dalej było podzielone w tej kwestii. Ilustracją tego jest wyrok WSA w Poznaniu ${ }^{14}$, w którym sąd wyraża następujący pogląd: „Do zachowania terminu określonego w art. 145 ust. 2 ustawy o gospodarce nieruchomościami musi istnieć w obrocie prawnym rozstrzygnięcie ustalające wysokość opłaty adiacenckiej wydane przed upływem okresu trzyletniego. Późniejsze wyeliminowanie z obrotu prawnego decyzji ustalającej wysokość tej opłaty, jeżeli upłynął już trzyletni termin do jej wydania, powoduje, że organ traci uprawnienie do kształtowania praw lub obowiązków jednostki w ramach administracyjno-prawnego stosunku materialnego, to jest traci

\footnotetext{
8 Por. wyroki NSA z dnia: 29 maja 2001 r., II SA/Po 336/00, ONSA 2002, nr 3, poz. 118; 13 grudnia 2001 r., I SA 1278/00, LEX nr 80650; 17 września 2003 r., I SA 345/01, niepubl.; ponadto wyroki WSA: w Gdańsku z dnia 23 maja 2007 r., II SA/Gd 161/07, ONSAiWSA 2008, nr 4, poz. 68, w Warszawie z dnia 20 marca 2009 r., I SA/Wa 86/09, LEX nr 557806; w Gdańsku z dnia 25 lutego 2009 r., II SA/Gd 634/08, LEX nr 1135389.

9 M.in. wyroki WSA: w Warszawie z dnia 22 listopada 2007 r., I SA/Wa 955/07, LEX nr 454099; w Poznaniu z dnia 20 listopada 2007 r., III SA/Po 468/07, LEX nr 454069.

10 E. Mzyk [w:] idem, G. Bieniek, S. Kalus, Z. Marmaj, Ustawa o gospodarce nieruchomościami. Komentarz, Warszawa 2008, s. 513.

11 Uchwała NSA z dnia 27 lipca 2009 r., I OPS 4/09, ONSAiWSA 2009, nr 5, poz. 84.

12 Por. wyrok WSA w Poznaniu z dnia 10 czerwca 2015 r., IV SA/Po 254/15, LEX nr 1734001 oraz wyrok WSA w Szczecinie z 26 kwietnia 2017 r., II SA/Sz 257/17, LEX nr 2290710.

13 E. Bończak-Kucharczyk, Ustawa o gospodarce nieruchomościami. Komentarz aktualizowany, art. 145, LEX/el. 2020. Por. wyroki WSA w Poznaniu: z dnia 26 lutego 2015 r., II SA/Po 1204/14, LEX nr 1653323; z dnia 26 czerwca 2014 r., II SA/Po 380/14, LEX nr 1503884; z dnia 26 czerwca 2014 r., II SA/ Po 520/14, LEX nr 1503896; oraz wyrok WSA w Bydgoszczy z dnia 3 sierpnia 2016 r., II SA/Bd 417/16, LEX nr 2121388.

14 Wyrok WSA w Poznaniu z dnia 19 kwietnia 2017 r., IV SA/Po 36/17, LEX nr 2275137.
} 
kompetencje do wydania decyzji określającej wysokość opłaty adiacenckiej". W uzasadnieniu wyroku sąd traktuje to stanowisko jako „pogląd prawny" powszechnie wyrażany w utrwalonym orzecznictwie sądów administracyjnych, wskazując na szereg orzeczeń sądowych ${ }^{15}$, a także na ustalenia doktryny ${ }^{16}$. Wojewódzki Sąd Administracyjny w Białymstoku uzupełnił ${ }^{17}$ te rozważania, twierdząc, że nie można za spełnienie ustawowego wymogu dochowania trzyletniego terminu na wydanie decyzji uznać przypadku wydania w sposób wadliwy tej decyzji, która została następnie w całości wyeliminowana z obrotu prawnego ${ }^{18}$. Późniejsze wyeliminowanie z obrotu prawnego decyzji ustalającej wysokość tej opłaty, jeżeli upłynął już trzyletni termin do jej wydania, miało powodować, że organ traci kompetencje do wydania decyzji określającej wysokość opłaty adiacenckiej ${ }^{19}$.

Zapadały także wyroki zgodne z uchwałą z dnia 27 lipca 2009 r., I OPS 4/09, z przywołaniem wyrażonego tam poglądu. Przykładowo - wyrok WSA w Szczecinie, gdzie sąd stwierdza: „3-letni termin z art. 145 ust. 2 u.g.n. jest terminem materialnym i dla jego zachowania konieczne jest wydanie decyzji przez organ I instancji, przy czym rozstrzygnięcie to nie musi mieć przymiotu ostateczności"20. Wojewódzki Sąd Administracyjny w Łodzi rozwija ${ }^{21}$ to stanowisko, twierdząc: „W orzecznictwie sądów administracyjnych ugruntowany jest pogląd, że termin trzyletni do wydania decyzji ustalającej opłatę adiacencką obowiązuje wyłącznie organ I instancji. (...) Termin ten nie może być stosowany w sprawie, w której sąd administracyjny uchylił decyzje wydane z jego zachowaniem. Funkcją terminu określonego w art. 145 ust. 2 ustawy o gospodarce nieruchomościami jest ograniczenie w czasie niepewności co do możliwości ustalenia opłaty adiacenckiej. Zauważyć bowiem należy, że stosownie do treści art. 145 ust. 1 ustawy o gospodarce nieruchomościami organ administracji może ustalić opłatę adiacencką. Zatem, jeżeli już raz w tym terminie decyzja została doręczona, przy czym jak się przyjmuje wystarczy doręczenie decyzji organu pierwszej instancji, to ustaje stan

15 Por. wyroki WSA w Poznaniu: z dnia 21 czerwca 2012 r., IV SA/Po 183/12; z dnia 30 sierpnia 2012 r., IV SA/Po 200/12; z dnia 17 stycznia 2013 r., IV SA/Po 510/12; z dnia 7 marca 2013 r., II SA/Po 822/12; z dnia 25 kwietnia 2013 r., II SA/Po 6/13; z dnia 4 września 2013 r., II SA/Po 664/13, z dnia 16 stycznia 2014 r., IV SA/Po 650/13; z dnia 12 marca 2014 r., II SA/Po 30/14, z dnia 26 czerwca 2014 r.; oraz wyroki WSA w Szczecinie z dnia: 29 maja 2013 r., II SA/Sz 298/13 i II SA/Sz 294/13; oraz 13 czerwca 2013 r., II SA/Sz 297/13; oraz wyrok WSA w Łodzi z dnia 27 sierpnia 2013 r., II SA/Łd 266/13. Wyroki dostępne w Centralnej Bazie Orzeczeń Sądów Administracyjnych (CBOSA; orzeczenia.nsa.gov.pl).

16 A. Skomra, P. Daniel, Termin ustalenia opłaty adiacenckiej, „Finanse Komunalne” 2013, nr 6. s. 32. Można tu przywołać także wyrok WSA w Gdańsku z dnia 23 marca 2017 r., II SA/Gd 633/16, LEX nr 2269647.

17 Wyrok WSA w Białymstoku z dnia 17 stycznia 2017 r., II SA/Bk 779/16, LEX nr 2197573.

18 Por. też wyrok WSA w Poznaniu z dnia 19 kwietnia 2017 r., IV SA/Po 36/17, LEX nr 2275137.

19 Zob. wyroki WSA w Poznaniu z dnia: 15 października 2015 r., II SA/Po 339/15, LEX nr 1932826; 25 lutego 2015 r., IV SA/Po 1023/14, LEX nr 1653521; 25 lutego 2015 r., IV SA/Po 1110/14, LEX nr 1653529; 25 lutego 2015 r., IV SA/Po 1229/14, LEX nr 1653558; wyrok WSA w Krakowie z dnia 14 stycznia 2015 r., II SA/Kr 1573/14, LEX nr 1643935; wyrok WSA w Gliwicach z dnia 13 sierpnia 2014 r., II SA/GI 581/14, LEX nr 1513338.

20 Wyrok WSA w Szczecinie z dnia 8 czerwca 2018 r., II SA/Sz 254/17. Podobnie ten sam sąd w wyroku z dnia 26 kwietnia 2017 r., II SA/Sz 257/17.

21 Wyrok WSA w Szczecinie z dnia 23 stycznia 2018 r., II SA/Łd 890/17, LEX nr 244216. 
niepewności co do skorzystania przez właściwy organ ze swoich uprawnień. Za taką wykładnią przemawia potrzeba zapewnienia, aby kontrolna w stosunku do administracji publicznej funkcja sądu administracyjnego nie była wykorzystywana do uniemożliwienia realizacji zadań tej administracji22. Skłania to do tezy, że działanie sądu administracyjnego, będące nawet skutkiem wadliwego działania organów administracji (wyrok uwzględniający skargę), nie może pozbawiać tych organów przyznanych im przez ustawę kompetencji, w tym także pośrednio, poprzez upływ czasu wyznaczonego przez ustawę do załatwienia sprawy"23.

Mimo niejednolitości orzecznictwa, zważywszy na przewagę orzeczeń przemawiających na rzecz innej opcji aniżeli wyrażona w przywoływanej uchwale, można jednak przyjąć, że większość składów orzekających podzielała drugie stanowisko. Od razu trzeba jednak zastrzec, że stanowiska te nie muszą być ze sobą do końca sprzeczne, skoro NSA w przyjętej uchwale wypowiadał się jedynie co do wydania w terminie trzyletnim decyzji przez organ pierwszej instancji, a nie rozważał skutków wyeliminowania tej decyzji z obrotu prawnego tak przez organ odwoławczy, jak i przez sąd administracyjny.

6. Pogląd, jaki zarysował się w obu orzeczeniach NSA, przy czym wyraźnie został wyeksponowany w pierwszym z glosowanych wyroków, jest następujący: „Decyzją określoną w art. 145 ust. 2 zdanie pierwsze ustawy o gospodarce nieruchomościami (o treści obowiązującej przed 23 sierpnia 2017 r.) jest decyzja organu pierwszej instancji niezależnie od tego, czy decyzja ta, w wyznaczonym przez ustawodawcę terminie trzech lat, stała się ostateczna i niezależnie od tego, czy to ta decyzja [podkr. A.M.] stała się ostateczna"24.

W drugim z glosowanych wyroków analogiczny, w istocie rzeczy, pogląd został sformułowany nieco inaczej: „W sytuacji, w której przed upływem trzyletniego terminu, o którym mowa w tym przepisie wydana została decyzja organu pierwszej instancji, późniejsze jej uchylenie nie wyłącza możliwości ustalenia opłaty adiacenckiej poprzez wydanie kolejnej decyzji"25.

Argumentacja uzasadniająca obie, zbieżne tezy, była jednak różna. W uzasadnieniu pierwszego wyroku za podstawę wzięto przede wszystkim wspomnianą wyżej uchwałę składu siedmiu sędziów z dnia 27 lipca 2009 r., I OPS 4/09. Natomiast w drugim, argumentacja była inna.

W konsekwencji tych orzeczeń stan rzeczy jest taki, że NSA dopuszcza możliwość wydania nowej decyzji pierwszoinstancyjnej po upływie trzyletniego terminu, i to tak po uchyleniu jej przez organ odwoławczy, jak i przez sąd administracyjny, w tym nawet przez NSA, w wyniku skargi kasacyjnej, na mocy której uchyla on wyrok sądu pierwszej instancji oraz decyzje: odwoławczą i pierwszoinstancyjną. Co więcej, jak należy się domyślać (aczkolwiek tego w uzasadnieniu wyroków nie stwierdzono, chociaż do

22 Oryginalny argument, sugerujący możliwość nadużycia prawa przez sąd administracyjny.

23 Tak też WSA w Gdańsku w wyroku z dnia 25 lutego 2009 r., II SA/Gd 634/08.

24 Zob. teza pierwszego glosowanego wyroku I OSK 85/18.

25 Zob. teza drugiego glosowanego wyroku I OSK 200/18. 
tego one prowadzą), nawet uchylenie decyzji w wyniku wznowienia i merytoryczne orzekanie przez organ wznowieniowy otwierałoby również taką możliwość. Poza tym, bez znaczenia pozostaje powód uchylenia decyzji pierwszoinstancyjnej, a zwłaszcza jej wadliwość, nawet jeśli jest ona najdalej idąca.

7. Od razu trzeba zauważyć, że nawiązanie w pierwszym wyroku do uchwały NSA z dnia 27 lipca 2009 r., I OPS 4/09 jest zbyt daleko idące. Uchwała ta zapadła w odpowiedzi na pytanie prawne skierowane przez skład orzekający NSA postanowieniem ${ }^{26}$, na podstawie art. 187 § 1 p.p.s.a ${ }^{27}$, do składu siedmiu sędziów, na tle konkretnego stanu faktycznego. Mianowicie, w terminie trzyletnim organ pierwszej instancji podjął i doręczył decyzję ustalającą opłatę, natomiast organ drugiej instancji rozpatrywał odwołanie już po upływie tego terminu. Przyjął, że w terminie tym powinna być wydana decyzja ostateczna, wobec czego uchylił zaskarżone rozstrzygnięcie i umorzył postępowanie pierwszoinstancyjne jako bezprzedmiotowe.

Teza pierwsza ww. uchwały I OPS 4/09 brzmi następująco: „Trzyletni termin, o którym mowa w art. 145 ust. 2 ustawy z dnia 21 sierpnia 1997 r. o gospodarce nieruchomościami (Dz. U. z 2004 r. Nr 261, poz. 2603 ze zm.), dotyczy rozstrzygnięcia przez organ pierwszej instancji o ustaleniu opłaty adiacenckiej".

Jak wynika z uzasadnienia uchwały, za stanowiskiem tam wyrażonym przemawiają zasady wykładni systemowej oraz zasady prokonstytucyjnej wykładni przepisów ustawowych. Przeciwne stanowisko prowadziłoby do możliwości różnego traktowania podmiotów znajdujących się w takiej samej sytuacji, w zależności tylko od tego, czy wnoszą oni odwołania, czy nie korzystają z takiego środka procesowego. Stanowiłoby to naruszenie zasady równości wynikającej z art. 32 Konstytucji RP.

Za takim stanowiskiem, jak czytamy w uzasadnieniu, przemawia także wykładnia celowościowa. W tym zakresie bowiem można odwołać się do wskazanych wyżej skutków terminów materialnych. Mimo że pociągają one za sobą także konsekwencje procesowe, podstawowe znaczenie powinny mieć, w razie wątpliwości, skutki materialnoprawne. Skutki takie zaś należy odróżnić od kwestii wykonalności decyzji. Ponieważ terminy materialne odnoszą się do okresu, w którym może nastąpić ukształtowanie określonych praw i obowiązków, wiązać je należy już z decyzją pierwszoinstancyjną. Dotyczą one ustalenia, stworzenia, zniesienia lub zmiany konkretnych praw i obowiązków skonkretyzowanego zewnętrznego adresata. Są efektem stanu prawnego obowiązującego w dniu wydania decyzji pierwszej instancji, aczkolwiek sytuacja w tym zakresie może ulec zmianie w toku postępowania odwoławczego. Czymś innym jest natomiast kwestia odroczonej wykonalności decyzji nieostatecznej.

Wracając do powyższej tezy zawartej w uchwale - NSA stwierdza, że trzyletni termin, o którym mowa w art. 145 ust. 2 u.g.n., dotyczy wydania decyzji ustalającej opłatę adiacencką przez organ pierwszej instancji. Sąd nie zajmował się innymi kwestiami, a w szczególności nie podjął rozważań, czy decyzja pierwszoinstancyjna wydana

\footnotetext{
26 Postanowienie NSA z dnia 26 listopada 2008 r., I OSK 1601/07, LEX nr 575842.

27 Przy rozpoznawaniu skargi kasacyjnej wyłoniło się zagadnienie prawne budzące poważne wątpliwości.
} 
w tym terminie, od której jeszcze przed jego upływem wniesiono odwołanie, musi stać się ostateczna w wyniku rozstrzygnięcia organu drugiej instancji. Nie rozważał także zagadnienia, czy po uchyleniu decyzji przez organ odwoławczy i przekazaniu sprawy do ponownego rozpatrzenia, będzie jeszcze możliwe wydanie nowej decyzji mimo upływu terminu itd.

Po tej uchwale zapadały wyroki ${ }^{28}$ NSA (powiązane z uchwałą ze względu na analogiczny stan prawny i faktyczny) gdzie również przyjęto, że przed upływem terminu z art. 145 ust. 2 u.g.n. opłata adiacencka może być ustalona decyzją nieostateczną. Wszczęcie postępowania administracyjnego i wydanie decyzji przed upływem przedawnienia, jak przyjęto, jest skuteczne także wówczas, gdy decyzja taka staje się ostateczna po upływie trzech lat.

Natomiast w większości orzeczeń sądów administracyjnych podejmowanych po uchwale zdecydowanie dominowało stanowisko, zgodnie z którym trzyletni termin należy rozumieć jako termin do określenia wysokości należnej opłaty, a nie jako termin do wyrażenia przez organ zamiaru skorzystania ze swoich uprawnień do wymierzenia opłaty. Wobec osoby objętej obowiązkiem uiszczenia opłaty adiacenckiej, po wyeliminowaniu z obrotu decyzji, nie może się bowiem aktualizować ponownie stan niepewności, przed którym miał chronić termin z art. 145 ust. 2 u.g.n. Jeśli termin ten upłynął, nie jest już możliwe ustalenie opłaty, a wszczęte postępowanie podlega umorzeniu jako bezprzedmiotowe ${ }^{29}$.

8. Nie można przejść do porządku nad rozważanym problemem, nie dostrzegając stanowiska NSA wyrażanego w analogicznych sprawach, tzn. takich, gdzie ustawodawca wyznacza termin materialnoprawny, a więc nieprzywracalny, do podjęcia przez organ administracji publicznej decyzji ustalającej (konstytutywnej). Wskażmy dwa przykłady, budzące do pewnego momentu podobne spory, jak kwestia terminu z art. 145 ust. 2 u.g.n.

Pierwszy przykład - podobną konstrukcję, jak w art. 145 ust. 1 u.g.n. przyjęto w przepisie art. 98a ust. 1 zdanie trzecie tej ustawy odnośnie do terminu, w jakim właściwy organ mógł ustalić wysokość opłaty adiacenckiej od podziału nieruchomości. Ukształtował się pogląd, że upływ trzyletniego terminu, o którym mowa w art. 98a ust. 1 u.g.n., dotyczy rozstrzygnięcia o ustaleniu opłaty adiacenckiej decyzją ostateczną. Stanowisko takie, wskazując na rozbieżności w orzecznictwie sądowym, wyrażono w wyroku NSA w składzie siedmiu sędziów z dnia 11 stycznia 2010 r. „Upływ trzyletniego terminu, o którym mowa w art. 98a ust. 1 ustawy z dnia 21 sierpnia 1997 r. o gospodarce nieruchomościami (Dz. U. z 2004 r. Nr 261, poz. 2603 ze zm.), dotyczy rozstrzygnięcia o ustaleniu opłaty adiacenckiej decyzją ostateczną" ${ }^{\prime 30}$.

28 Wyroki NSA z dnia 7 kwietnia 2010 r., I OSK 102/10, LEX nr 575942 oraz I OSK 101/10, LEX nr 575941. 29 Wyroki NSA z dnia: 27 sierpnia 2015 r., I OSK 2815/13, 6 września 2017 r., I OSK 303/17; oraz z dnia 21 marca 2018 r., I OSK 1395/16; także wiele wyroków WSA, w tym m.in.: w Poznaniu z dnia 15 października 2015 r., II SA/Po 339/15; w Szczecinie z dnia 8 czerwca 2017 r., II SA/Sz 254/17; w Gdańsku z dnia 13 lutego 2018 r., II SA/Gd 513/17.

30 Tak NSA w wyroku wydanym w składzie siedmiu sędziów (w wyniku przejęcia do rozpoznania na podstawie art. 187 § 3 p.p.s.a.) z dnia 11 stycznia 2010 r., I OPS 5/09, ONSAiWSA 2010, nr 3, poz. 43 (w sprawie przejętej do rozpoznania przez skład siedmiu sędziów na podstawie art. 187 § 3 p.p.s.a.) 
W kwestii tej zapadła także uchwała NSA w składzie siedmiu sędziów z dnia 25 listopada 2013 r., precyzująca w zasadzie pojęcie ostateczności decyzji odwoławczej31: "O zachowaniu trzyletniego terminu dla ustalenia opłaty adiacenckiej z tytułu wzrostu wartości nieruchomości w wyniku jej podziału, o którym mowa w art. 98a ust. 1 u.g.n., w przypadku zakończenia postępowania decyzją organu odwoławczego, decyduje data wydania decyzji ostatecznej przez organ odwoławczy, a nie data doręczenia tej decyzji stronie".32 Do poglądu tego nie stosowano się jednak konsekwentnie ${ }^{33}$.

Pojawia się oczywiście pytanie, czy można mówić o pełnej analogii między normami zawartymi w art. 145 ust. 2 i 98 ust. 1 u.g.n. w okresie, w którym uchwały te zapadały, skoro treść regulacji była różna. Artykuł 98a ustawy został dodany ustawą zmieniającą ${ }^{34}$, która weszła w życie z dniem 22 września 2004 r. Przed tą datą do opłat adiacenckich z tytułu wzrostu wartości nieruchomości w wyniku jej podziału, z mocy art. 98 ust. 4 u.g.n., miał odpowiednie zastosowanie art. 145 tej ustawy. Jego ust. 2 stanowił, że ustalenie opłaty adiacenckiej może nastąpić w terminie do trzech lat od dnia urządzenia lub modernizacji drogi albo od stworzenia warunków do podłączenia nieruchomości do poszczególnych urządzeń infrastruktury technicznej. Odpowiednie zastosowanie tego przepisu do opłat związanych ze wzrostem wartości nieruchomości z tytułu jej podziału oznaczało, że ustalenie tej opłaty mogło nastąpić w terminie do trzech lat od dnia, w którym decyzja zatwierdzająca podział nieruchomości stała się ostateczna. W stanie prawnym obowiązującym przed 22 września 2004 r. i w orzecznictwie, i w doktrynie przyjmowany był pogląd, że przed upływem trzyletniego terminu powinna zapaść decyzja ostateczna, naliczająca opłatę adiacencką, w tym związaną ze wzrostem wartości nieruchomości z tytułu podziału ${ }^{35}$.

Natomiast po zmianie, a więc w okresie nas interesującym, przepis stanowiący podstawę do ustalenia opłaty adiacenckiej od podziału brzmiał w sposób następujący:

31 Uchwała NSA z dnia 25 listopada 2013 r., I OPS 6/13, ONSAiWSA 2014, nr 2, poz. 18.

32 Przepis stanowiący podstawę do ustalenia opłaty adiacenckiej od podziału brzmiał w sposób następujący: „Ustalenie opłaty adiacenckiej może nastąpić w terminie 3 lat od dnia, w którym decyzja zatwierdzająca podział nieruchomości stała się ostateczna albo orzeczenie o podziale stało się prawomocne". Po zmianie dokonanej art. 1 pkt 20 lit. a ustawy z dnia 20 lipca 2017 r. zmieniającej u.g.n.: „Ustalenie opłaty adiacenckiej może nastąpić w terminie do 3 lat od dnia, w którym decyzja zatwierdzająca podział nieruchomości stała się ostateczna albo orzeczenie o podziale stało się prawomocne", a więc podobnie jak w przypadku art. 145 ust. 2 u.g.n.

33 Ilustracją tego jest wyrok NSA z dnia 18 marca 2014 r., I OSK 2666/12, LEX nr 1487797: „Bieg 3-letniego terminu przedawnienia określonego w przepisie art. 98a ust. 1 u.g.n., na podstawie art. 123 § 1 ustawy z dnia 23 kwietnia 1964 r. - Kodeks cywilny (Dz. U. z 2014 r. poz. 121) w zw. z art. 148 ust. 2 u.g.n., znajdującym odpowiednie zastosowanie do ustalenia opłaty adiacenckiej z tytułu wzrostu wartości nieruchomości wywołanego podziałem nieruchomości, przerywa wydanie przez organ ostatecznej decyzji ustalającej opłatę adiacencką. W sytuacji zaskarżenia ww. decyzji do sądu administracyjnego, na podstawie art. 148 ust. 2 u.g.n. w zw. z art. 124 § 1 i 2 Kodeksu cywilnego, termin przedawnienia biegnie na nowo od dnia uprawomocnienia się wyroku sądu uchylającego decyzję ustalającą opłatę adiacencką".

34 Ustawa z dnia 28 listopada 2003 r. o zmianie ustawy o gospodarce nieruchomościami oraz o zmianie niektórych innych ustaw (Dz. U. Nr 141, poz. 1492).

35 G. Bieniek, et al., Komentarz do ustawy o gospodarce nieruchomościami, t. 2, Zielona Góra 2000, S. 212. 
„Ustalenie opłaty adiacenckiej może nastąpić w terminie 3 lat od dnia, w którym decyzja zatwierdzająca podział nieruchomości stała się ostateczna albo orzeczenie o podziale stało się prawomocne", podczas gdy zmieniony ww. ustawą oraz kolejną z dnia 24 sierpnia 2007 r. ${ }^{36}$ art. 145 ust. 2 stanowił: „Wydanie decyzji o ustaleniu opłaty adiacenckiej może nastąpić w terminie do 3 lat od dnia stworzenia warunków do podłączenia nieruchomości do poszczególnych urządzeń infrastruktury technicznej albo od dnia stworzenia warunków do korzystania z wybudowanej drogi, jeżeli w dniu stworzenia tych warunków obowiązywała uchwała rady gminy, o której mowa w art. 146 ust. 2".

Jak NSA podkreślił w wyroku I OPS 5/09 z dnia 11 stycznia 2010 r., odmienności zachodzące między opłatą adiacencką z art. 98a ustawy a opłatą adiacencką, o której mowa w art. 145 ustawy, prowadzą do wniosku, że ustawodawca z tego powodu zróżnicował przepisy dotyczące przedawnienia tych opłat. „W przypadku opłaty, o której mowa w art. 98a ustawy, mającej charakter w pełni daninowy, związany z uzyskaniem korzyści na skutek samego podziału nieruchomości, przyjęto co do przedawnienia bardziej rygorystyczne dla gminy rozwiązanie, polegające na tym, że w terminie 3 lat od podziału opłata musi być ostatecznie ustalona. Natomiast w przypadku opłaty adiacenckiej, o której mowa w art. 145 ustawy, przyjęto rozwiązanie co do przedawnienia, że w terminie 3 lat od stworzenia warunków do podłączenia nieruchomości do infrastruktury technicznej albo do korzystania z wybudowanej drogi ma być wydana decyzja o ustaleniu opłaty adiacenckiej przez wójta (burmistrza, prezydenta miasta)".

Drugi przykład - dotyczy terminu do wniesienia sprzeciwu w przypadku budowy na podstawie art. 30 ust. 5 prawa budowlanego ${ }^{37}$. Naczelny Sąd Administracyjny wyraził stanowisko ${ }^{38}$, które było ukształtowane i aprobowane wcześniej w orzecznictwie i doktrynie: „Termin z art. 30 ust. 5 p.b. ma charakter terminu prawa materialnego, który nie podlega przedłużeniu, a jego upływ powoduje utratę przez właściwy organ kompetencji do wydania decyzji wnoszącej sprzeciw. Wniesienie odwołania od decyzji o sprzeciwie nie powoduje przedłużenia materialnoprawnego terminu do wydania decyzji. Z tego względu organ odwoławczy nie może zastosować art. 138 § 2 k.p.a., uchylić decyzji i przekazać sprawy do ponownego rozpatrzenia, gdy upłynął termin do wniesienia sprzeciwu. Z analogicznych powodów nie może organ odwoławczy, po upływie terminu do wniesienia sprzeciwu, uchylić decyzji organu pierwszej instancji i orzec w sprawie co do istoty, skoro kompetencja organów do wniesienia sprzeciwu wygasła".

W orzecznictwie sądowoadministracyjnym, jak wyjaśniono w uzasadnieniu, jednolicie przyjmuje się, że termin z art. 30 ust. 5 prawa budowlanego ma charakter terminu prawa materialnego, który nie podlega przedłużeniu, a jego upływ powoduje utratę przez właściwy organ kompetencji do wydania decyzji wnoszącej sprzeciw.

\footnotetext{
36 Artykuł 1 pkt 48 ustawy z dnia 24 sierpnia 2007 r. o zmianie ustawy o gospodarce nieruchomościami oraz o zmianie niektórych innych ustaw (Dz. U. Nr 173, poz. 1218). Zmiana polegała na uzupełnieniu przepisu o końcową część: „(...) jeżeli w dniu stworzenia tych warunków obowiązywała uchwała rady gminy, o której mowa w art. 146 ust. 2".

37 Ustawa z dnia 7 lipca 1994 r. - Prawo budowlane (Dz. U. Nr 89, poz. 414; dalej: prawo budowlane).

38 Wyrok z dnia 11 stycznia 2018 r., II OSK 1159/17, LEX nr 2442873.
} 
Taka charakterystyka omawianego terminu ma wpływ na katalog rozstrzygnięć, jakie może w konsekwencji wydać organ pierwszej instancji i organ odwoławczy, rozpoznając odwołanie od decyzji organu pierwszej instancji. Organ odwoławczy, rozpoznając odwołanie od decyzji o sprzeciwie, może orzec o jej utrzymaniu w mocy. Może też orzec o jej uchyleniu i umorzeniu postępowania w sytuacji, gdy uzna decyzję organu pierwszej instancji za wadliwą, a termin ustalony do wydania decyzji już upłynął. Wniesienie odwołania od decyzji o sprzeciwie nie powoduje przedłużenia materialnoprawnego terminu do wydania decyzji. Z tego względu organ odwoławczy nie może zastosować art. 138 § 2 k.p.a., uchylić decyzji i przekazać sprawy do ponownego rozpatrzenia, gdy upłynął termin do wniesienia sprzeciwu. Z analogicznych powodów nie może organ odwoławczy, po upływie terminu do wniesienia sprzeciwu, uchylić decyzji organu pierwszej instancji i orzec w sprawie co do istoty, skoro kompetencja organów do wniesienia sprzeciwu wygasła ${ }^{39}$.

9. Podsumowując wnioski wynikające z orzecznictwa sądowego, jak i doktryny, która za nim podążała, należy zwrócić uwagę na kilka kwestii: po pierwsze - autorzy orzeczeń zdają sobie sprawę z tego, że skutek upływu terminu materialnego, wyznaczonego przez ustawodawcę do wydania konstytutywnej decyzji administracyjnej, jest oczywisty - w tym terminie powinna być wydana decyzja ostateczna, przy czym w przypadku decyzji odwoławczej wystarczy jej podjęcie, bez konieczności doręczania; po drugie - mają jednak świadomość tego, że skutek taki, oznaczający w istocie rzeczy możliwość uchylenia się od obowiązków wynikających z decyzji, jest trudny do zaakceptowania z punktu widzenia podstawowych wartości konstytucyjnych (m.in. sprawiedliwość, równość); po trzecie - szukają, w związku z tym, różnych dróg prawnych (interpretacji) mających na celu „ucieczkę" od skutków przedawnienia ${ }^{40}$; po czwarte - wraz z akceptacją dla celu tych poszukiwań rodzi się pytanie, czy poszukiwania te nie prowadzą do uzyskania takich rezultatów, które moglibyśmy kwalifikować jako sprzeczne z prawem; po piąte wreszcie - czy jedyną drogą prowadzącą do eliminacji tych negatywnych skutków przedawnienia nie jest zmiana przepisów, tak jak to uczynił ustawodawca w przypadku art. 98a ust. 1 oraz art. 145 ust. 2 u.g.n.? Zmiany te, oznaczające w zasadzie rezygnację z przedawnienia (liczy się nie wydanie decyzji, ale wszczęcie postępowania), mogą potwierdzać spostrzeżenie poczynione na wstępie. Ustawodawca miał świadomość, że dotychczasowe uregulowania wskazują na przedawniający charakter terminu, a tym samym na konieczność ustalenia opłaty adiacenckiej w drodze ostatecznej decyzji administracyjnej.

10. Termin z art. 145 ust. 2 u.g.n. jest terminem prawa materialnego ${ }^{41}$, odnoszącym się do organu. Niezachowanie takiego terminu powoduje wygaśnięcie uprawnienia, roszczenia, a termin ten nie może być żadnym środkiem prawnym przedłużony czy też przywrócony. Upływ terminu powoduje utratę możliwości działania przez organ.

\footnotetext{
39 Por. np. wyroki NSA z dnia: 11 kwietnia 2014 r. II OSK 2767/12; 20 października 2015 r., II OSK 1397/15, CBOSA [orzeczenia.nsa.gov.pl].

40 Zwrócono na to uwagę w zdaniu odrębnym do uchwały NSA z 27 lipca 2009 r., I OPS 4/09.

41 Mam na uwadze oczywiście termin wskazany w art. 154 ust. 2 przed zmianą tego przepisu.
} 
Sprawa, której dotyczy, powinna zostać zakończona przez organ przed upływem terminu, bo potem organ nie będzie mógł działać, to jest korzystać ze swego uprawnienia.

Innymi słowy rzecz ujmując, termin materialnoprawny został wyznaczony dla organu do ukształtowania w drodze konstytutywnej decyzji administracyjnej pewnego uprawnienia (obowiązku). Rodzi się zatem pytanie, w którym momencie następuje ukształtowanie tego obowiązku, a w szczególności - czy w dacie wydania decyzji, czy też w innym momencie.

By rozwikłać ten problem, trzeba sięgnąć do ustaleń doktryny dotyczących konstrukcji decyzji administracyjnej. Jest ona aktem o mieszanym charakterze - z jednej strony ma bowiem wymiar materialny, wyrażając się właśnie w indywidualnym ukształtowaniu konkretnego prawa czy obowiązku, z drugiej zaś strony - stanowi akt procesowy, kończący postępowanie i przybierający określoną formę, przewidzianą przez prawo procesowe (art. 107 k.p.a.). Ta forma procesowa służy temu w istocie, aby materialną treść decyzji wprowadzić do obrotu prawnego. Bez takiego wprowadzenia decyzja materialna nie istnieje w sensie takim, że decyzja nie wywiera skutków prawnych, jakie z nią będą związane.

Decyzja administracyjna to „władcze, jednostronne oświadczenie woli organu administracji publicznej (lub innego podmiotu sprawującego w zleconym mu zakresie funkcje administracji publicznej), skierowane do zewnętrznego adresata, rozstrzygające indywidualną sprawę administracyjną (autorytatywnie konkretyzujące administracyjnoprawny stosunek materialny), podjęte na podstawie i w celu konkretyzacji generalno-abstrakcyjnych norm prawnych powszechnie obowiązujących oraz normy kompetencyjnej, w trybie i w formie przewidzianej normami proceduralnymi, kończące administracyjne postępowanie jurysdykcyjne"42.

W definicji tej kładzie się nacisk na decyzję jako akt stosowania prawa, ale także na aspekt materialny i formalny. Decyzją administracyjną organ administracji, działając na podstawie normy kompetencyjnej, dokonuje formalnej czynności konwencjonalnej będącej aktem konkretyzacji lub aktualizacji treści abstrakcyjnych i generalnych norm materialnych prawa administracyjnego, tworząc indywidulaną normę prawną o charakterze pochodnym ${ }^{43}$. Norma ta określa w sposób jednostronny i władczy prawa i obowiązki podmiotu poddanego procesowi konkretyzacji normy materialnej prawa administracyjnego. Proces konkretyzacji, skutkujący wydaniem decyzji, w istocie rzeczy kończy się nie w momencie podjęcia czy doręczenia decyzji, ale w dacie uzyskania przez decyzję waloru ostateczności. Oczywiście, decyzja pierwszoinstancyjna może stać się ostateczna po upływie czternastu dni, pod warunkiem niewniesienia od niej odwołania. Jeśli jednak odwołanie zostanie wniesione, to decyzja organu pierwszej instancji, niemająca znamion ostateczności, po wniesieniu odwołania staje się jedynie

\footnotetext{
42 T. Woś [w:] Postępowanie administracyjne, red. idem, Warszawa 2017, s. 347. Podobnie J. Zimmermann, Polska jurysdykcja administracyjna, Warszawa 1996, s. 133-140; oraz C. Martysz [w:] idem, G. Łaszczyca, A. Matan, Postępowanie..., s. 649-654.

43 T. Woś [w:] Postępowanie administracyjne..., s. 375.
} 
"określoną propozycją" co do treści rozstrzygnięcia ${ }^{44}$. Odwołanie w postępowaniu administracyjnym powoduje przeniesienie pełnej kompetencji do rozstrzygnięcia sprawy - na organ wyższego stopnia, z tym skutkiem, że orzeczenie pierwszej instancji automatycznie upada ${ }^{45}$. Jeśli orzeczenie organu odwoławczego ma charakter merytoryczny, to ono $w$ istocie rozstrzyga sprawę ${ }^{46}$. Pogląd taki znajduje umocowanie w zasadzie dwuinstancyjności postępowania administracyjnego oraz związanej z nią tokiem instancji. Na rzecz tego stanowiska przemawia także i to, że przedmiotem zaskarżenia do sądu administracyjnego mogą być jedynie decyzje ostateczne. Ograniczenie zaskarżalności do decyzji administracyjnej ostatecznej wynika z przyczyn, o jakich mówimy. Natomiast formalnie wynika to z rozwiązań prawnych przyjętych w art. $52 \S 1$ p.p.s.a., który wprowadza dopuszczalność skargi na decyzje administracyjne wydane na podstawie przesłanki wyczerpania środków zaskarżenia.

Można jedynie rozważać kwestię tego rodzaju: czy decyzja organu odwoławczego utrzymująca w mocy decyzję organu pierwszej instancji nie przywraca tej ostatniej do życia, skoro prowadzi do uzyskania przez nią ostateczności? Dosyć trudno byłoby taką konstrukcję przyjąć, zwłaszcza stojąc na gruncie zasady dwuinstancyjności, zakładającej obowiązek ponownego rozpatrzenia sprawy przez organ drugiej instancji i wydanie przez niego orzeczenia (nowego). Zatem utrzymanie w mocy może oznaczać tylko tyle, że organ odwoławczy podjął identyczne co do treści rozstrzygnięcie.

11. Nie ma wystarczających podstaw do tego, aby z niespornego faktu, iż termin wskazany w art. 145 ust. 2 u.g.n. jest terminem materialnym, wyciągać inne wnioski inne niż sformułowane wyżej (tj. przemawiające za wydaniem decyzji ostatecznej przed upływem terminu trzyletniego). Charakterystyczny pogląd dla tej linii orzeczniczej,

\footnotetext{
44 T. Kiełkowski, Nabycie prawa..., s. 195.

45 M. Zimmermann [w:] idem, W. Brzeziński, M. Jaroszyński, Polskie prawo administracyjne, Warszawa 1956, s. 377-378. Podobnie, aczkolwiek nie tak stanowczo: G. Łaszczyca, komentarz do art. 15 k.p.a. (teza 6) [w:] idem, C. Martysz, A. Matan, Kodeks postępowania administracyjnego. Komentarz, t. 1, Komentarz do art. 1-103: „Dla uznania zatem, iż zasada dwuinstancyjności postępowania została zrealizowana, nie wystarczy samo stwierdzenie, że w sprawie zapadły dwa rozstrzygnięcia dwóch organów różnych stopni. Poprzestanie na takim ustaleniu oznaczałoby formalne rozumienie zasady (por. wyr. NSA z dnia 20 maja 1998 r., IV SA 2058/97, niepubl.). Toteż właściwe wypełnienie zasady dwuinstancyjności wymaga nie tylko podjęcia dwóch kolejnych rozstrzygnięć różnych organów, lecz zakłada ich podjęcie w wyniku przeprowadzenia przez każdy z tych organów postępowania umożliwiającego osiągnięcie celów, dla których postępowanie to jest prowadzone (por. wyr. NSA z dnia 29 kwietnia 1999 r., I SA/Łd 112/98, niepubl.; wyr. NSA z dnia 12 listopada 1992 r., V SA 721/92, ONSA 1992, nr 3-4, poz. 95). Chodzi zatem o to, by »przeprowadzono dwukrotnie merytoryczne postępowanie, by dwukrotnie oceniono dowody, w sposób rzeczowy i poważny przeanalizowano wszelkie argumenty i opinie, i w konsekwencji doprowadzono do wydania takiego rozstrzygnięcia, które najlepiej odpowiadać będzie prawu, interesowi publicznemu i słusznym interesom strony « (uzasadnienie uch. SN z dnia 1 grudnia 1994 r., III AZP 8/94, OSNAPiUS 1995, nr 7, poz. 82). Po wstępnej kontroli wymogów formalnych zwykłego środka prawnego, organ II instancji powinien przystąpić do ponownego rozpatrzenia sprawy tak jak gdyby nie było rozstrzygnięcia organu I instancji".

46 T. Kiełkowski, Nabycie prawa..., s. 195. Jak piszą T. Woś i J. Zimmermann w glosie do uchwały SN z dnia 23 września 1986 r.:„,Od strony teoretycznej można by przyjąć, że pierwsze rozstrzygnięcie przestaje obowiązywać z chwilą, gdy zdecydowano się na powtórzenie postępowania w sprawie, która musi i tak zakończyć się nowym rozstrzygnięciem".
} 
która upatruje w materialnym charakterze możliwości wydania w okresie trzyletnim decyzji nieostatecznej, NSA wyraził w uchwale z dnia 27 lipca 2009 r., I OPS 4/09, odnosząc je do skutków tego rodzaju terminów. „Mimo że pociągają one za sobą także konsekwencje procesowe, podstawowe znaczenie powinny mieć, w razie wątpliwości, skutki materialnoprawne. Skutki takie zaś należy odróżnić od kwestii wykonalności decyzji. Ponieważ terminy materialne odnoszą się do okresu, w którym może nastąpić ukształtowanie określonych praw i obowiązków, wiązać je należy już z decyzją pierwszoinstancyjną. Dotyczą one ustalenia, stworzenia, zniesienia lub zmiany konkretnych praw i obowiązków skonkretyzowanego zewnętrznego adresata. Są efektem stanu prawnego obowiązującego w dniu wydania decyzji pierwszej instancji, aczkolwiek sytuacja w tym zakresie może ulec zmianie w toku postępowania odwoławczego Czymś innym jest natomiast kwestia odroczonej wykonalności decyzji nieostatecznej".

Skutki decyzji należy rzeczywiście odróżniać od jej wykonalności, ale nie oznacza to, że niewykonalność decyzji zupełnie rozmija się z jej skutecznością. Skutki prawne decyzji administracyjnej, w ogólnym tego słowa znaczeniu, są bardzo rozległe, mają naturę nie tylko materialną, ale i procesową. Do bezpośrednich skutków materialnych decyzji konstytutywnych należy ukształtowanie określonych praw czy obowiązków beneficjenta aktu (strony sensu stricto). Decyzja pośrednio kształtuje pozycję materialnoprawną także pozostałych stron postępowania (oczywiście w innym zakresie niż głównego adresata aktu). Poza tym, z decyzją wiąże się zazwyczaj szereg innych praw i obowiązków, wynikających bezpośrednio z ustawy, powiązanych z decyzją, a w zasadzie z charakterem uprawnień (obowiązków) z niej wynikających (weźmy pod uwagę chociażby pozwolenie budowlane i rozliczne obowiązki obciążające inwestora, wynikające z prawa budowlanego, ale także z prawa ochrony środowiska, prawa sanitarnego, prawa geodezyjnego i kartograficznego itd.). To wszystko trzeba zaliczyć do skutków decyzji. Dopiero w tym kontekście możemy oceniać kwestię skuteczności decyzji rozumianą jako spowodowanie sytuacji, w której wszystkie konsekwencje materialnoprawne wywołane decyzją stają się wiążące (stają się prawem).

Natomiast wykonanie oznacza spowodowanie takiego stanu w rzeczywistości społecznej, który jest zgodny z jej treścią ${ }^{47}$, a „wykonalność" to zdatność tego rozstrzygnięcia do wywoływania skutków bezpośrednio określonych w decyzji ${ }^{48}$. Zatem skuteczność (moc obowiązującą) decyzji odnosimy do stanu prawnego, zaś wykonanie do stanu faktycznego, a wykonalność stanowi swoisty łącznik między jednym a drugim, a w istocie mówi o zdolności decyzji do spowodowania określonego stanu w rzeczywistości społecznej. Dodajmy jeszcze to, ze nie każda decyzja skuteczna zdolność taką posiada (np. decyzja odmowna). Wykonalność stanowi jeden ze skutków decyzji, nie zawsze występujący.

\footnotetext{
47 J. Jendrośka, Zagadnienia prawne wykonania aktu administracyjnego, Wrocław 1963, s. 22; R. Sawuła, Wstrzymanie wykonania rozstrzygnięć wydanych w postępowaniu administracyjnym, PrzemyślRzeszów 2008, s. 53 i s. 109-110.

48 T. Woś [w:] Postępowanie administracyjne..., s. 418.
} 
Z przepisu art. 130 § 1 k.p.a., wyrażającego ustawową zasadę niewykonywania nieostatecznych decyzji przed upływem terminu do wniesienia odwołania, nie można wyprowadzać wniosku, iż decyzja organu pierwszej instancji stała się skuteczna, a jedynie ze względu na prawo do odwołania nie może być wykonywana. Inaczej rzecz ujmując, decyzja taka nie ma jeszcze „mocy wiążącej” w tym znaczeniu, że nie jest jeszcze skuteczna.

Na rzecz nieskuteczności decyzji pierwszoinstancyjnej przemawia także rozwiązanie przyjęte w art. 130 § 3 k.p.a., zgodnie z którym wskazana wyżej zasadę nie stosuje się w przypadkach, gdy decyzji został nadany rygor natychmiastowej wykonalności (art. 108) albo decyzja podlega natychmiastowemu wykonaniu z mocy ustawy. W tych sytuacjach, jak należy przyjąć, decyzja uzyskuje prowizoryczną skuteczność na mocy odrębnego aktu (postanowienia) bądź bezpośrednio na podstawie ustawy. Ta „prowizoryczna skuteczność" nie tkwi zatem w samej decyzji, ale ma źródło zewnętrzne, i może ona zostać unicestwiona na skutek uchylenia decyzji, jak i uchylenia tego aktu zewnętrznego.

Skutek w postaci ustalenia opłaty adiacenckiej nie powstaje w dacie wydania decyzji przez organ I instancji, ale w momencie, w którym decyzja ta staje się ostateczna ze względu na upływ terminu do wniesienia odwołania, bądź też staje się ostateczna decyzja organu odwoławczego, wydana w wyniku ponownego rozpoznania sprawy. To, że wyjątkowo decyzja pierwszoinstancyjna będzie podlegała wykonaniu, nie ma nic wspólnego z jej skutecznością. Oznacza to tylko tyle, że ustawodawca wyjątkowo dopuszcza możliwość wykonywania jeszcze nieukształtowanych uprawnień (obowiązków) przez adresata decyzji (na jego ryzyko).

W art. 145 ust. 2 u.g.n. nie chodzi o wydanie decyzji wykonalnej w zakreślonym terminie, ale o wydanie decyzji ustalającej, a więc skutecznie kształtującej obowiązek uiszczenia opłaty adiacenckiej. To że decyzja pierwszoinstancyjna została wydana w tym terminie nie oznacza jeszcze, że może być ona uznana za decyzję ustalającą w rozumieniu tego przepisu, skoro nie jest jeszcze skuteczna (nie ma mocy obowiązującej). W żaden sposób nie zmienia tego możliwość (wyjątkowa) jej wykonania.

12. We wcześniejszych rozważaniach przewijał się wątek przedawnienia, z jakim mieliśmy do czynienia w art. 145 ust. 2 u.g.n. do 22 sierpnia 2017 r. Zmiana przepisu, dokonana ustawą z dnia 20 lipca 2017 r. zmieniającą u.g.n., przedawnienie zniosła.

Przedawnienie, w ogólnym ujęciu, jest instytucją prawną, która z upływem wyznaczonego w przepisach prawa administracyjnego czasu oraz biernością uprawnionego do podjęcia określonego działania podmiotu, którym jest organ administracji publicznej albo podmiot prywatny, łączy skutek w postaci wygaśnięcia prawa do nałożenia na jednostkę obowiązku bądź też jego wykonania albo praw do uzyskania bądź realizacji przyznanego jednostce uprawnienia. Łączy skutek w postaci wygaśnięcia prawa do nałożenia na jednostkę obowiązku ${ }^{49}$. W naszym przypadku chodzi o przedawnienie odnoszące się do wygaśnięcia prawa organu gminy do nałożenia na jednostkę obowiązku w postaci opłaty adicenckiej po upływie trzyletniego terminu. Nie jest istotne,

49 W. Piątek, Przedawnienie w prawie administracyjnym, Poznań 2018, s. 156. 
jak to przedawnienie określimy - czy jako „przedawnienie orzekania przez organ”, czy „przedawnienie uprawnień procesowych" ${ }^{50}$, skoro nie budzi wątpliwości, że zmiana

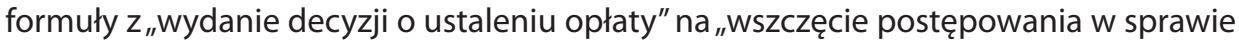
ustalenia opłaty" prowadzi do wniosku, że ustawodawca z jakichś przyczyn postanowił nie ograniczać czasowo uprawnienia gminy do nałożenia obowiązku partycypacji w kosztach budowy urządzeń infrastruktury technicznej w formie opłaty adiacenckiej. W terminie trzyletnim, który pozostał, ma ona jedynie wszcząć postępowanie. Dokładnie taki sam skutek wynika z glosowanych orzeczeń, przy czym odnosi się on do okresu, w którym uprawnienie gminy podlegało przedawnieniu. Już samo to stawia pod znakiem zapytania trafność wyroków, a być może nawet trzeba postawić pytanie, czy nie zachodzi tutaj stan contra legem. Pozostaje poza granicami uprawnień sądu administracyjnego eliminowanie (wyłączanie w konkretnym przypadku) przyjętej przez ustawodawcę instytucji prawnej. Przedawnienie ma na celu stabilizację sytuacji prawnej jednostki. Powinno gwarantować, że po upływie wskazanego w ustawie okresu nie musi się ona obawiać obciążenia obowiązkiem ${ }^{51}$. Instytucja ta spełnia także funkcję porządkującą (porządkuje „przestrzeń normatywną”), motywacyjną (poprawia efektywność administrowania) i wreszcie funkcję ochronną względem podmiotów administracji, które nie pozostają zobowiązane w nieskończoność do realizacji obowiązku ${ }^{52}$. W tym kontekście należy także oceniać trafność i prawidłowość tych wyroków.

13. Można mieć jeszcze inne uwagi dotyczące tezy zaprezentowanej w omawianych orzeczeniach. W szczególności chodzi o to, że składy orzekające nie dostrzegły różnicy zachodzącej między uchyleniem decyzji przez organ odwoławczy i orzeczeniem merytorycznym bądź przekazaniem sprawy do ponownego rozpatrzenia a uchyleniem decyzji drugoinstancyjnej i pierwszoinstancyjnej przez sąd administracyjny. W pierwszym przypadku uchylenie następuje w toku instancji, a więc w ramach zawisłej sprawy administracyjnej. W drugim zaś - uchylenia dokonuje sąd administracyjny w ramach sprawowanej kontroli, a więc poza tokiem instancji. Sprawa administracyjna została już zakończona decyzją ostateczną, a więc taką, która kończy proces stosowania normy generalnej i abstrakcyjnej, uzyskuje moc prawną, jest skuteczna erga omnes i nadaje się do wykonania. Uchylenie przez sąd administracyjny decyzji odwoławczej i decyzji pierwszoinstancyjnej powoduje, że decyzji ustalającej opłatę nie ma, jest jedynie wszczęte i niezakończone postępowanie w sprawie opłaty. A więc jest to problem, o którym była mowa wyżej. Nie wzięto pod uwagę skutków przedawnienia.

14. Wreszcie trzeba zwrócić uwagę na treść uzasadnień obu wyroków, która z kilku powodów nie zasługuje na aprobatę.

Po pierwsze - ze względu na argumentację tam zastosowaną, poczynając od tego, że jest ona zupełnie różna. Jak się należy domyślać, sąd, wydając pierwszy z wyroków, kierował się uchwałą NSA z dnia 27 lipca 2009 r. Jeśli chodzi o drugi wyrok, to

\footnotetext{
50 Ibidem, s. 121.

51 Tak w uzasadnieniu projektu ustawy Przepisy ogólne prawa administracyjnego odnośnie do art. 16, „Biuletyn RPO” 2008, nr 60, s. 84-85.

52 O funkcjach przedawnienia: W. Piątek, Przedawnienie..., s. 164-172.
} 
decydujące znaczenie miała kwestia ochrony interesów właściciela nieruchomości (z chwilą wydania decyzji o ustaleniu opłaty adiacenckiej ustaje stan niepewności co do tego, czy opłata adiacencka zostanie nałożona czy też nie) oraz zasada równości (uprzywilejowanie tych, którzy złożyli odwołanie). Co do uchwały, to wniosek, jaki z niej wyprowadził sąd, jest za daleko idący (o czym była mowa wcześniej). W kwestii argumentów zawartych w uzasadnieniu drugiego wyroku stwierdzić trzeba, że stan niepewności ustaje dopiero po wydaniu decyzji ostatecznej. Jeśli chodzi o zachowanie równości to rzeczywiście jest z tym pewien problem, ale ta nierówność nie jest wynikiem działania organu administracji czy sądu, ale samego ustawodawcy. Byłaby to zatem „nierówność w prawie”, którą powinien usunąć ustawodawca, a nie organy stosujące prawo.

Po drugie - z przyczyny braku odniesienia do linii orzeczniczej, jaka wykształciła się na tle art. 145 ust. 2 u.g.n. w brzmieniu obowiązującym do 22 sierpnia 2017 r., zwłaszcza po podjęciu uchwały NSA z 27 lipca 2009 r. W uzasadnieniach wyroków, wbrew przyjętym zasadom, NSA nawet nie wspomniał o ukształtowaniu się stanowiska tak samego NSA, jak i sądów wojewódzkich, zmierzającego w stronę przyjęcia opcji wydania decyzji ostatecznej przed upływem terminu trzyletniego. Nawet jeśli stanowisko to nie było wyraźnie utrwalone, to wypadało o nim wspomnieć i przytoczyć argumenty na rzecz opcji przeciwnej. Szkoda, że sąd nie skorzystał z sugestii organu odwoławczego, autora skargi kasacyjnej, który proponował poddanie tego zagadnienia prawnego, budzącego poważne wątpliwości, rozszerzonemu składowi w celu podjęcia uchwały

Po trzecie - za wadliwością uzasadnienia (uzasadnień) przemawia także brak jakiejkolwiek refleksji w kwestii zmiany charakteru terminu przedawniającego, który, w wyniku stanowiska wyrażonego w wyrokach, przestał takim być. Nie ma tu znaczenia decyzja ustawodawcy, który nowelizacją z dnia 20 lipca 2017 r. zmieniającą u.g.n. zrezygnował z tak rozumianego terminu trzyletniego do ustalenia opłaty adiacenckiej. Ustawodawca mógł to uczynić, natomiast pozostawało to poza zakresem uprawnień sądu.

\section{Literatura}

Bieniek G., Hopfer A., Marmaj Z., Mzyk E., Źróbek R., Komentarz do ustawy o gospodarce nieruchomościami, t. 2, Zielona Góra 2000.

Bieniek G., Kalus S., Marmaj Z., Mzyk E., Ustawa o gospodarce nieruchomościami. Komentarz, Warszawa 2008.

Bończak-Kucharczyk E., Ustawa o gospodarce nieruchomościami. Komentarz aktualizowany, art. 145, LEX/el. 2020.

Jendrośka J., Zagadnienia prawne wykonania aktu administracyjnego, Wrocław 1963.

Kiełkowski T., Nabycie prawa na mocy decyzji administracyjnej, Warszawa 2012.

Łaszczyca G., Martysz C., Matan A., Kodeks postępowania administracyjnego. Komentarz, t. 1, Komentarz do art. 1-103, Warszawa 2010.

Piątek W., Przedawnienie w prawie administracyjnym, Poznań 2018. 
Sawuła R., Wstrzymanie wykonania rozstrzygnięć wydanych w postępowaniu administracyjnym, Przemyśl-Rzeszów 2008.

Skomra A., Daniel P., Termin ustalenia opłaty adiacenckiej, „Finanse Komunalne” 2013, nr 6.

Postępowanie administracyjne, red. T. Woś, Warszawa 2017.

Zimmermann J., Polska jurysdykcja administracyjna, Warszawa 1996.

Zimmermann M. [w:] idem, W. Brzeziński, M. Jaroszyński, Polskie prawo administracyjne, Warszawa 1956.

\section{Streszczenie}

\section{Andrzej Matan}

\section{Termin na wydanie decyzji o ustaleniu opłaty adiacenckiej (art. 145 ust. 2 u.g.n.)}

Jak przyjął NSA w komentowanych wyrokach, w sytuacji gdy przed upływem trzyletniego terminu materialnoprawnego wydana została decyzja organu pierwszej instancji, późniejsze jej uchylenie nie wyłącza możliwości ustalenia opłaty adiacenckiej poprzez wydanie kolejnej decyzji. Pogląd ten nie zasługuje na aprobatę, bowiem samo wniesienie odwołania powoduje upadek decyzji organu pierwszej instancji. Staje się ona jedynie "określoną propozycją" co do treści rozstrzygnięcia. Odwołanie w postępowaniu administracyjnym powoduje przeniesienie pełnej kompetencji do rozstrzygnięcia sprawy na organ wyższego stopnia z tym skutkiem, że orzeczenie pierwszej instancji automatycznie upada. Jeśli orzeczenie organu odwoławczego ma charakter merytoryczny, to ono w istocie rozstrzyga sprawę.

Wobec tego wyeliminowanie z obrotu prawnego decyzji pierwszoinstancyjnej tak ze względu na wniesione odwołanie, jak i w wyniku wyroku sądu administracyjnego powoduje utratę kompetencji organu administracji do orzekania w sprawie. To z kolei skutkuje koniecznością umorzenia postępowania.

\section{Summary}

\section{Andrzej Matan}

Time limit for issuing a decision determining the adjacency fee (art. 145 p. 2 of the Act on Land Management)

As the Supreme Administrative Court assumed in the commented judgments, in a situation where a decision of the first instance authority was issued before the expiry of the three-year substantive period, its subsequent repeal does not exclude the possibility to determine the adjacency fee by issuing another decision. This view does not deserve approval, as the lodging of an appeal results in the fall of the first instance authority's decision. It becomes only a "specific proposal" as to the content of the decision. An appeal in administrative proceedings transfers full competence to settle the case to a higher authority, with the result that the first-instance judgment automatically falls. If the decision of the appeal body is substantive, it will, in fact, decide the case. 
Therefore, the elimination of the first-instance decision from legal circulation, both due to the appeal lodged and as a result of an administrative court judgment, results in the loss of the competence of the administrative authority to adjudicate in the case. This in turn results in the need to discontinue the proceedings.

Słowa kluczowe: wyrok sądu, termin materialnoprawny, decyzja ostateczna, umorzenie postępowania

Keywords: court verdict, substantive deadline, final decision, discontinuation of proceedings 